Arch. hist. jap. Vol. 16, n. 3 (March 1959). P. $467-485$.

1st Dept. of Anat., Kyushu Dental College, Kokura (Chief: Prof. Taneaki NAKAYAMA). Dept. of Path., School of Dent., Nihon Univ., Tokyo (Chief: Prof. Yozo KOBAYAKAWA).

\title{
Electron Microscope Studies of the Tissue Structure of the Enamel Lamella.
}

\author{
エナメル葉組織構造の電子顕微鏡的研究.
}

\author{
Yasuyuki AWAZAWA* 粟 沢 靖 之,
}

(Received January 20, 1959.)

Ever since the discovery of the enamel lamella by BÖDECKER in 1909, opinions have been expressed one after another concerning the histological nature of the lamella. Scholars do not agree even today as to what tissues compose the lamella. BÖDECKER (1909) reported his findings that the lamella is a part of the enamel in which abundant organic matter is contained. EBNER (1922) and MEYER (1926), on the other hand, regarded the lamella as being either that part of the residual enamel that has not yet fully calcified or that has incompletely calcified. BAUMGARTNER (1911) and WALKHOFF (1924) felt that the lamella consists of imperfectly calcified enamel rods. GOTTLIEB (1921) claimed the lamella is soft tissue composed of enamelblasts, enamel pulp, external enamel epithelium etc. This soft tissue filled the enamel cracks formed in the process of tooth development, this area later keratinized. ORBAN (1926) explained that the lamella is either a keratinized tissue that is identical with the enamel cuticle or that the lamella consists of the incompletely calcified enamel. GRÄFF (1921), AKAMATSU (1928) and SCHULZ (1933) regarded the lamella as an artificial product which appears in the enamel in the preparation of specimens. The difference of opinions probably exists because of the extreme difficulty in studying the composition of a structure so small as a lamella. Some of the histologists mentioned above could not observe the lamella's exact structure even under the highest magnification of a light microscope. Accordingly their microscopic observation might have been strongly colored by their previous deductions. Perhaps the lamella has not been truly identified up to this time since the histological definition has been interpreted in such an inexact manner. The reason why no electron microscope has been used in the investigation of the enamel lamella tissue may be that the method of collecting the lamella is extremely difficult. The primary difficulty is finding lamellae that run in a suitable direction for electron microscopy.

The author reported in a previous paper in 1953 that since bovine lamellae are so wide they enable one to observe their tissue structure quite clearly even under an ordinary microscope. The author found that the tissue structure of bovine lamellae consists of enamel rods and interrod substance in which organic matter abounds.

\footnotetext{
* At present in the Dept. of Pathology, School of Dentistry, Nihon University, Tokyo.
} 
In the present study the author observed the tissue structure of human and bovine lamellae with electron microscopy. These studies revealed that the lamella is a tissue, running in the enamel, which consists of enamel rods and interprismatic substance which contain more abundant organic matter than normal enamel. Occasionally the author observed an enamel lamella less than one micron in width which consisted only of interrod substance containing more organic matter than those of normal enamel. The findings are described in the following lines accompanied with explanations of their individual electron micrographs.

\section{Materials and Method.}

Normal teeth of human beings and cows were used for observation. The human teeth were prepared for the electron microscope immediately after extraction. They were extracted with slight force from alveoli afflicted with advanced acute periodontal disease. The bovine teeth were obtained and prepared immediately after the cows were killed. The teeth thus obtained were stained still remaining in the jaw bones. The staining method is described as follows: the teeth were placed in a 0.5 percent silver nitrate solution for 20 minutes stored in an incubator during this period. Following this, they were placed in a 2 percent gallic acid solution for half an hour also in the incubator to fully reduce the silver nitrate that had permeated the enamel tissue. The incubator temperature was always kept at $36^{\circ} \mathrm{C}$. The enamel surface was decalcified by washing the teeth in a 10 percent nitric acid solution for several seconds. This decalcification exfoliated the black reduced silver residue from the enamel surface so that the silver stained lamellae could be clearly seen in contrast to the milky-white enamel with the naked eye. Lamellae were then selected for electron microscopy. Except for a few specimens, the outer surfaces of the enamel and the lamella were slightly ground of $f$ and etched with hydrochloric acid for several seconds to better expose selected lamella. The filmy replicas were shadowed with chrome-carbon.

\section{Individual Findings.}

All specimens showed crystalline objects scattered on the enamel surfaces. Probably the crystalline objects originated from the redeposition of decalcified enamel or from the imperfect decalcification of enamel. Also the surfaces of the lamellae contain a few crystalline objects. This fact lends support to the supposition that abundant organic matter is contained in the lamella. However, crystalline objects are sometimes bunched on a certain portion of the lamella surface. These portions probably contain a high concentration of calcium salt deposits. The electron microscopic descriptions of the human and bovine lamellae are shown below.

\section{A. Human enamel lamellae.}

Fig. 1 shows a part of a lamella found on the mesial side of 5 of a male human adult, aged 37. On the enamel surface, which is darkened because of crystalline objects, a lamella, lying diagonally, is observed. The border lines between the 
enamel and the lamella are clearly seen.

Fig. 2 is the magnified photomicrogaph of Fig. 1. In this photo. both the enamel and the lamella are observed clearly. We can see four probable rods of

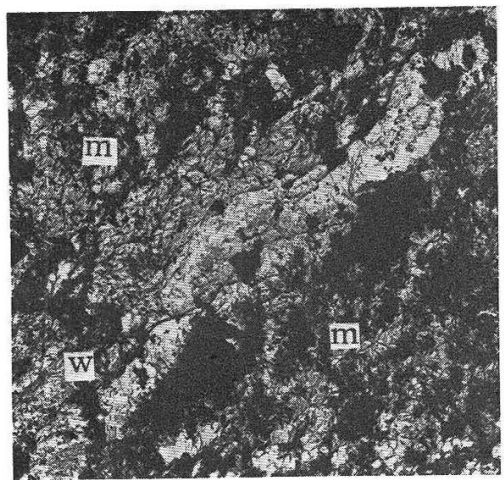

Fig. 1. The electron micrgraph of a part of an enamel lamella found on the mesio-proximal side of $5 \mid$, a male human adult, aged 37 . The enamel lamella lies diagonally in the figure. There are diffusely observable many crystalline objects on the enamel surface, while crystalline objects are seen lesser on the lamella. $w$ enamel lamella, $m$ enamel. The outer layer of one fourth of the enamel width was ground off, etched with 2 percent $\mathrm{HCl}$ for 4 sec., filmy replica shadowed with chrome-carbon. $\times 2,000$

Fig. 2. The magnification of Fig. 1. $\uparrow$ indicates the border line between the enamel and the lamella. The rods in the lamella are arranged in a line. $w$ lamella, $p$ rod in the lamella, $s$ rod sheah in the lamella, $m$ enamel.

lamella which are arranged in a single line. Fig. 3 is the partial magnification of Fig. 2. It is possible that the lamella tissue consists of enamel rods and interrod substance which contain more organic matter than those from normal enamol. In the central portion we notice that there are two cross-sectioned rod surfaces. Wach of these is bordered with dark and fine line that is probably rod sheath. Besides, a possible cross-sectioned rod can be seen in both the upper and lower parts of the photo. In each of the cross sections we see certain irregular square and oval apparances. 'These

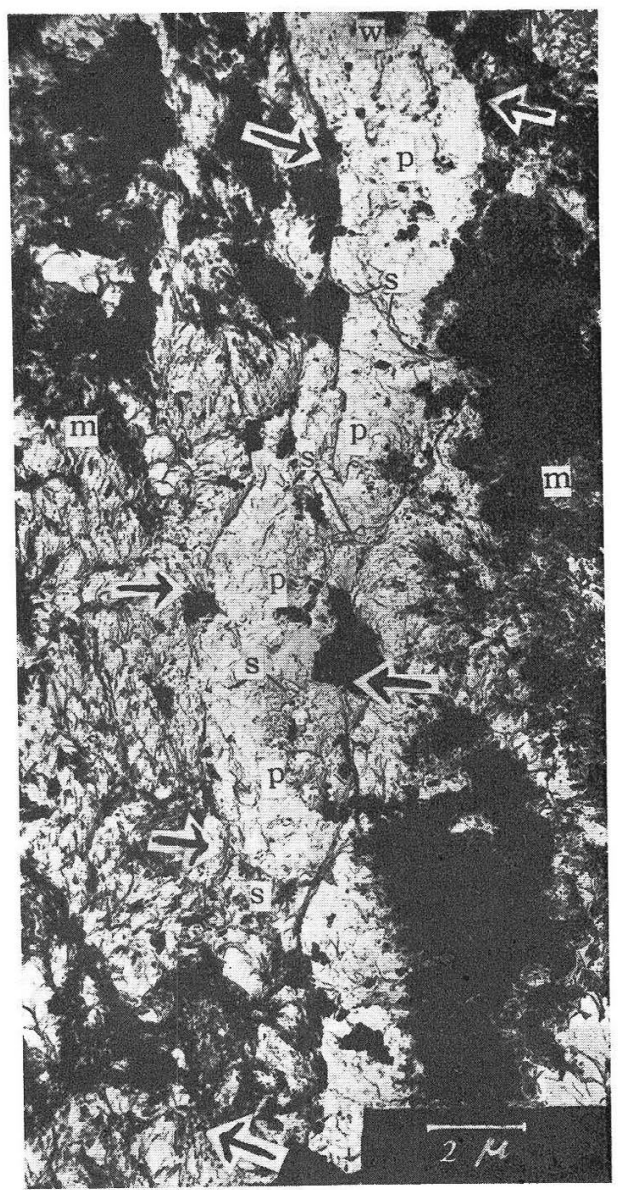




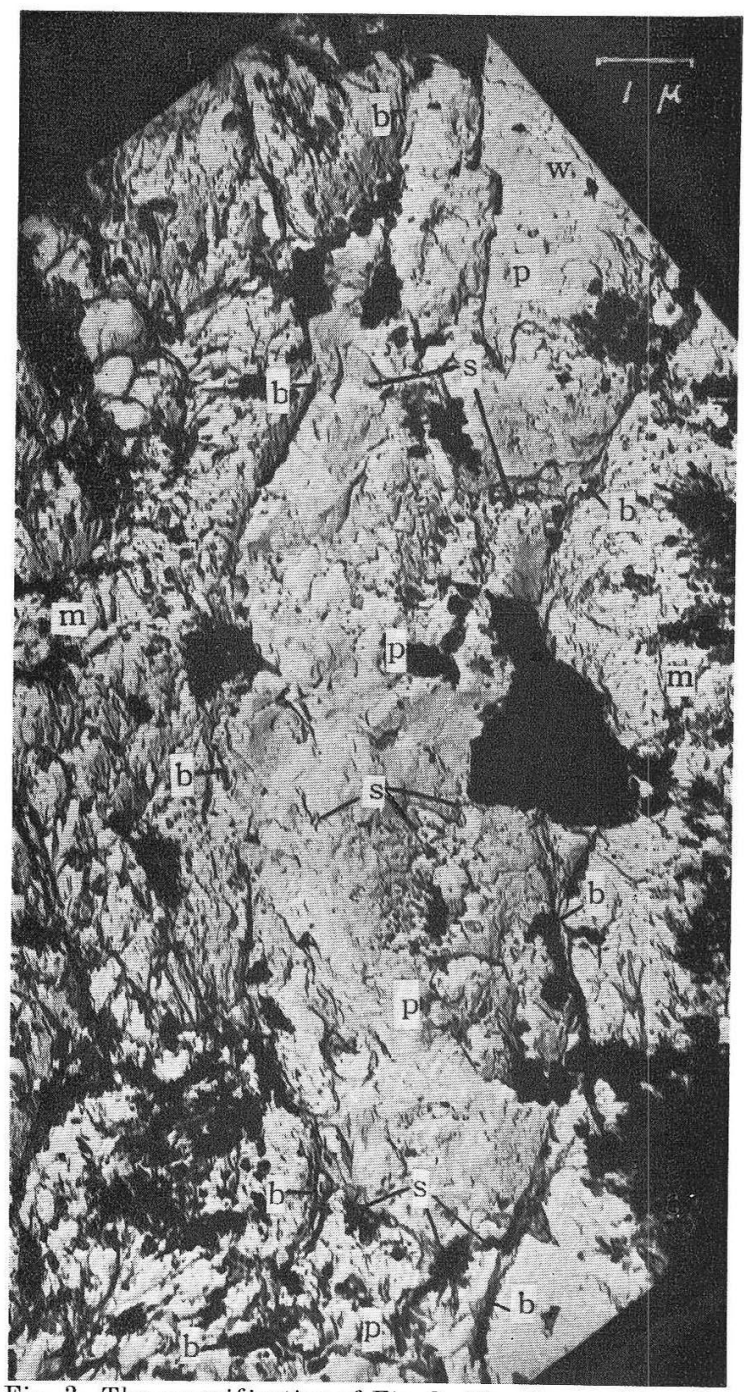

Fig. 3. The magnification of Fig. 2. The tissue of lamella probably consists of enamel rods and interrod substance in which abundant organic matter is contained. Two sectioned rods are seen in the lamella in the central portion. Another probable sectioned rod in the lamella is recognized in both the upper and lower portions of the picture. In these sectioned rods, there are observed certain irregular square and oval appearances which are surrounded by thin linear organic matters. $w$ lamella, $p$ rod in the lamella, $s$ rod sheath in the lamella, $b$ limiting line between the enamel and the lamella, $m$ enamel.

outlines are circumscribed by thin linear organic matters. Perhaps these are certain tissue structures which originated in the organic substances found in enamel 
rods involved in the lamella. As a result, the organic rod surfaces are divided into many sections of various sizes. Accordingly, it seems a rod in the lamella consists of a bundle of far smaller sectioned individual rods than those found in normal enamel.

Fig. 4 is a microphotograph taken of a lamella seen on the labial side of $\mid 1$, from a male human adult, aged 25. General observation shows that the enamel seems dartiened, while the enamel lamella is clearly revealed. Fig. 5 is the magnification of the upper half of Fig. 4. Undulatory outlines of sectioned enamel rods are observed. In the lamella, we recognize two sectioned possible rods in the lower part of the photo. The sheaths which appeared because of the decalcification

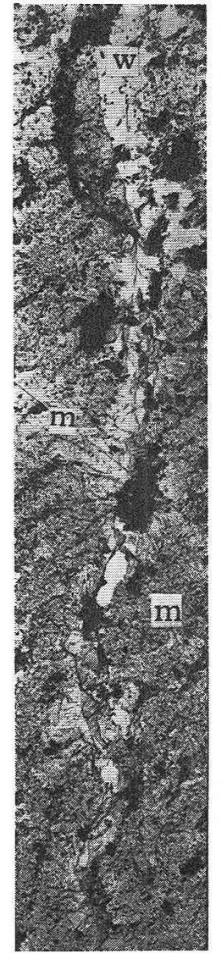

Fig. 4. The electron micrograph taken of a part of a lamella seen on the labial side of 1 , a male human adult, aged 25 . The clear lamella is seen in the dark enamel. $w$ enamel lamella, $m$ enamel. The outer layer of about one third of the enamel width was ground off, etched with 2 percent $\mathrm{HCl}$ for 3 ser., filmy replica shadowed with chrome-carbon. $\times 1,500$

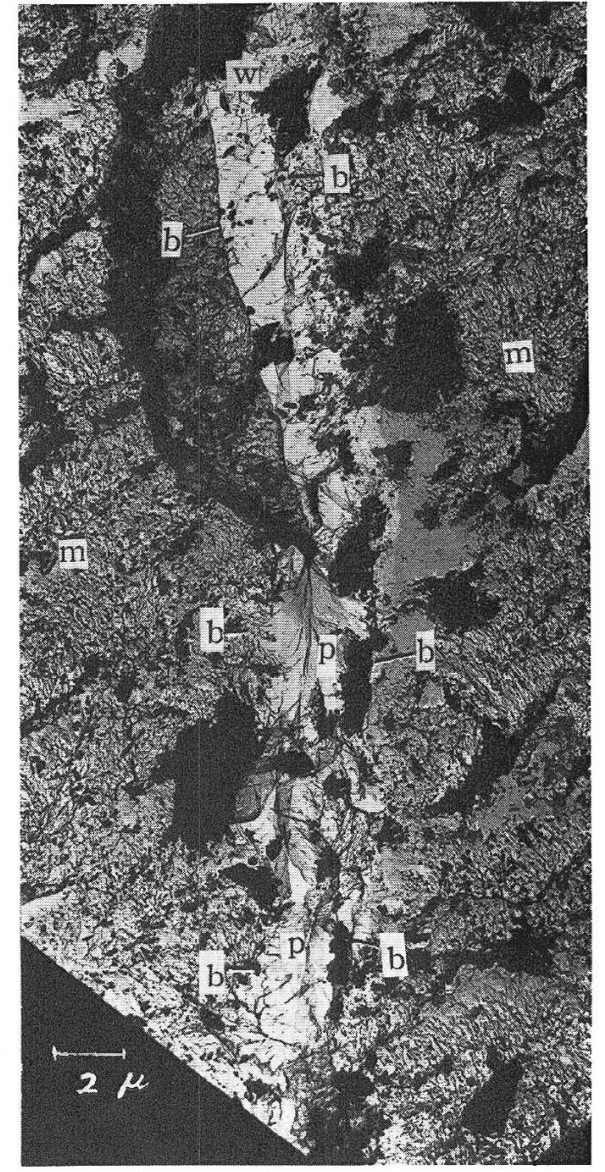

Fig. 5. The magnification of the upper half of Fig. 4. In the lamella tissue, two possible sectioned rods are recognized in the lower part of the photo. The border lines are observed along the lamella. $m$ enamel, $p$ rod in the lamella, $b$ border between the enamel and the lamella, $w$ lamella. 
may belong to the rods of lamella, as they are rarely found in other areas of enamel. Fig. 6 is the magnification of the lower half of Fig. 4. In this picture there is no outline of enamei rods in the lamella. However, the enamel lamella constituents are probably no different from those of the enamel. The interconnected rod sheaths appear to be a thin membrane along the whole lamella. Fig. 7 is the partial magnification of Fig. 6 . The lamella tissue is identical with enamel tissue. The tissue structure of lamella is clearly seen through the translucent rod sheaths. The thinness of this membrane indicates the membrane was formed by the organic rod sheaths, which belong to the lamelia.

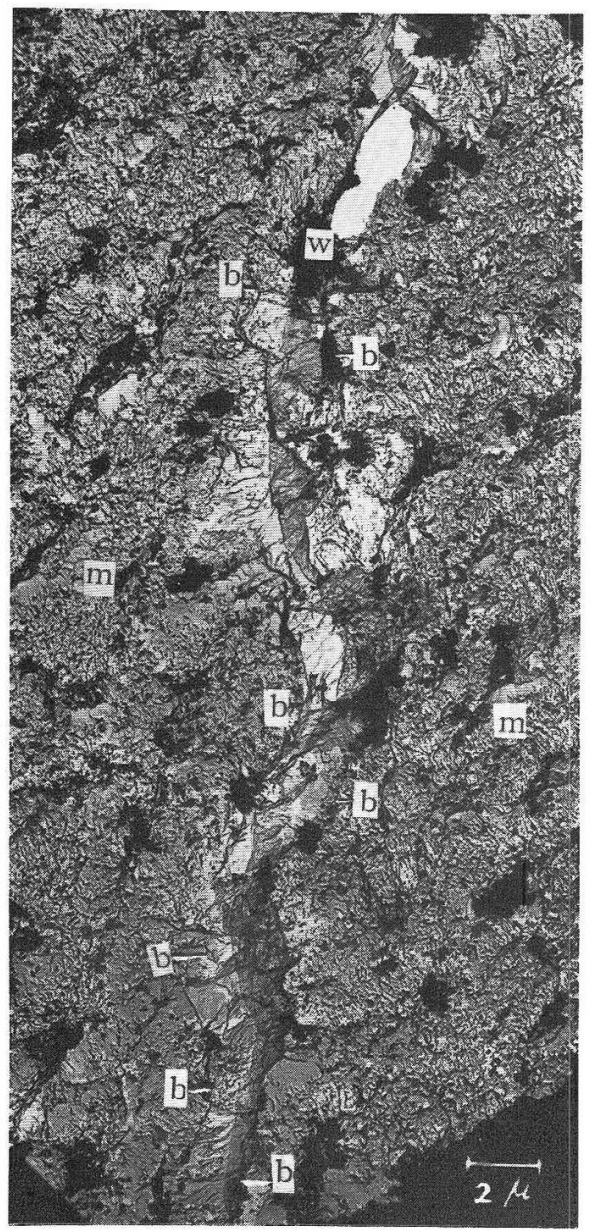

Fig. 6. The magnification of the lower half of Fig. 4. No outline of enamel rod is observed in the lamella. This finding, however, indicates that the lamella tissue is probably not different from that of the enamel. Rod sheaths exposed by decalcification are seen along the whole aspect of Iamella. $w$

lamella, $b$ boundary between the enamel and the lamella, $m$ enamel. 


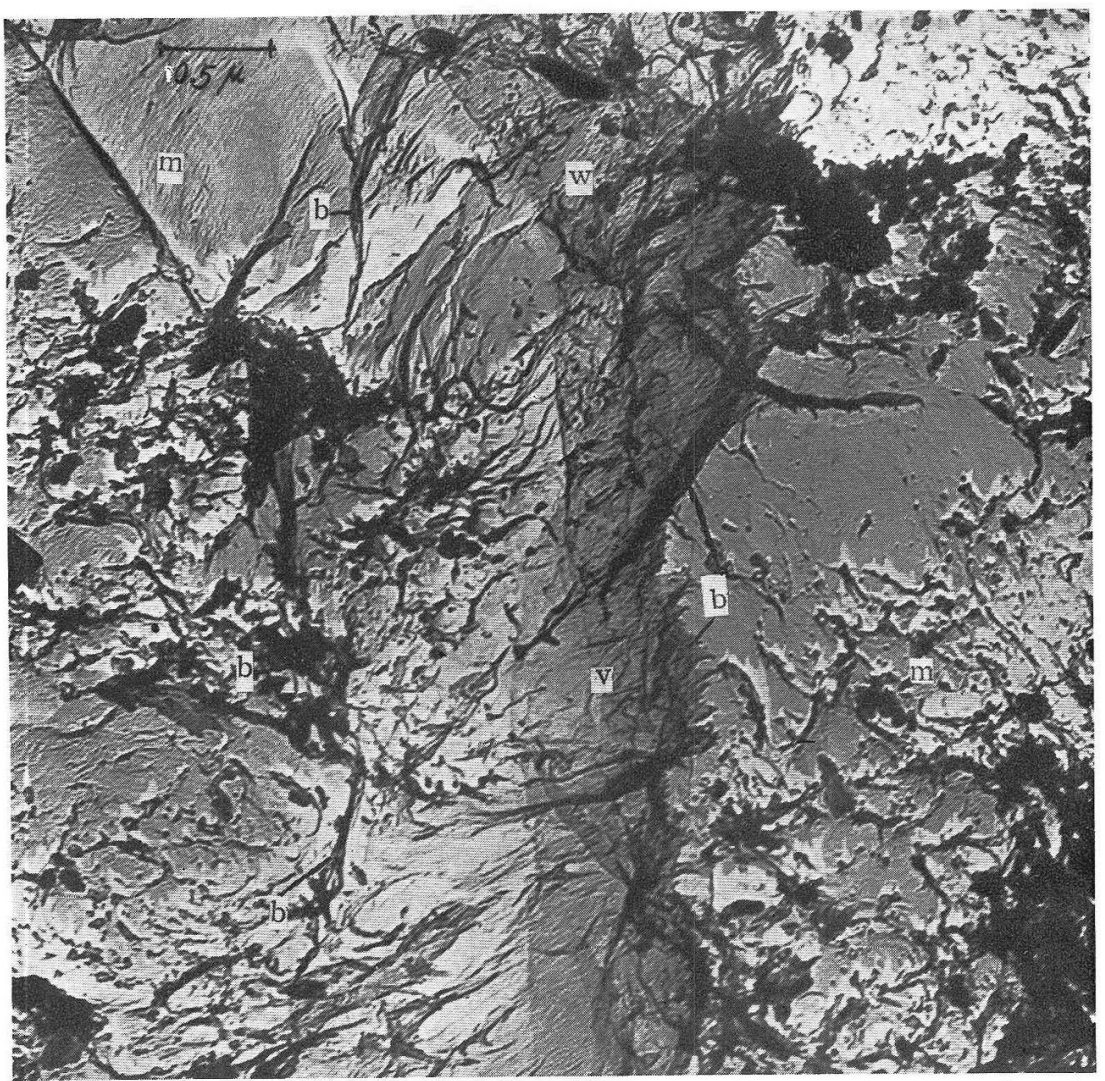

Fig. 7. The partial magnification of Fig. 6. The lamella tissue is observed to be identical with that of the enamel. A part of the tissue is clearly observed through the thin translucent sheath. Organic matters distributed in the enamel and the lamella are observed. $w$ enamel lamella, $b$ boundary between the lamella, $v$ rod sheath exposed by decalcification.

Fig. 8 is the photomicrograph in which a part of the lamella found on the labial side of 3$\rfloor$, a male human adult, aged 30 , is shown. In the enamel of the left lower half of the photo., two sectioned enamel rods are clearly seen. In the enamel of the right lower half of the photo., can be seen a sectioned enamel rod. The upper two thirds of the lamella is very narrow and there is no outline of enamel rod. In the lowest part of the lamella, can be seen a probable sectioned organic rod. Intarrod substance seems to compose the upper two thirds of the lamella since its width is less than one micron. It obviously contains more organic matter than the interrod substance of normal enamel. Dark interrod substances in the enamel can also be seen. A small portion of a rod sheath found along the right border of the upper part of the lamella probably belongs to an enamel rod lying adjacent to that part of the lamella, since that part of the lamella seems to contain only interrod substance as mentioned above. 


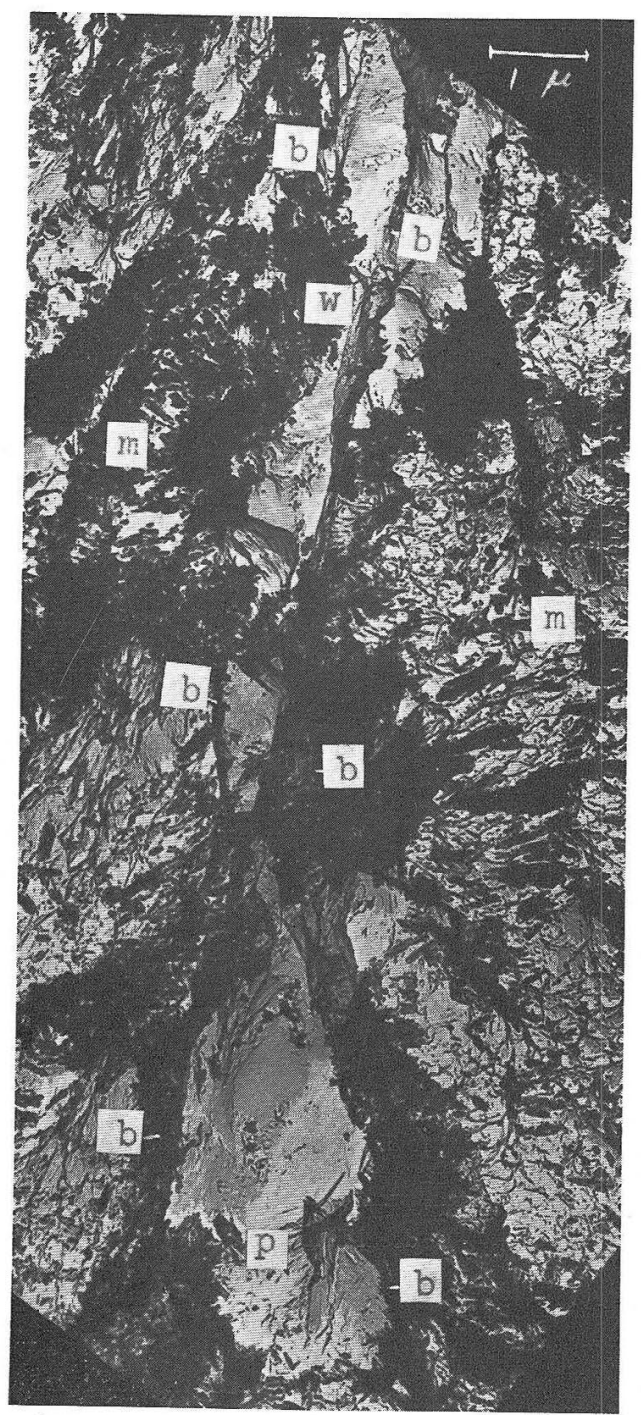

Fig. 8. The electron micrograph of a part of a lamella found on the labial side of $3 \mid$, a male human adult, aged 30. The upper two thirds of the lamella is observed to contain only of inter rod substances. $w$ enamel lamella, $p$ probable rod in the lamella, $b$ border between the enamel and the lamella, $m$ enamel. The outer layer of the enamel was decalcified with 10 percent HCI for about 10 sec., filmy replica shadowed with chrome-carbon.

Fig. 9 is another part of the lamella shown on Fig. 8 . The boundaries can be clearly seen between the enamel and lamella. The lamella tissue found in the upper half of the figure seems to be identical with the enamel tissue in the same vicinity. 
Rods found in that part of the lamella may be regarded as having been calcified to a higher degree. A rod sheath can be clearly seen at the left boundary of the lamella seen in the lower part of the photo.

Fig. 10 is a partial enlargement of the lower part of Fig 9. Numberless fibrils are clearly seen in a sectioned enamel rod contained in the lamella. These fibrils are scattered diffusely in a rather parallel manner and some of them are seen through the sheath exposed by decalcification. These fibrils strongly resemble collagenous fibrils. Hitherto these fibrils were considered nonexistent in the enamel rods.

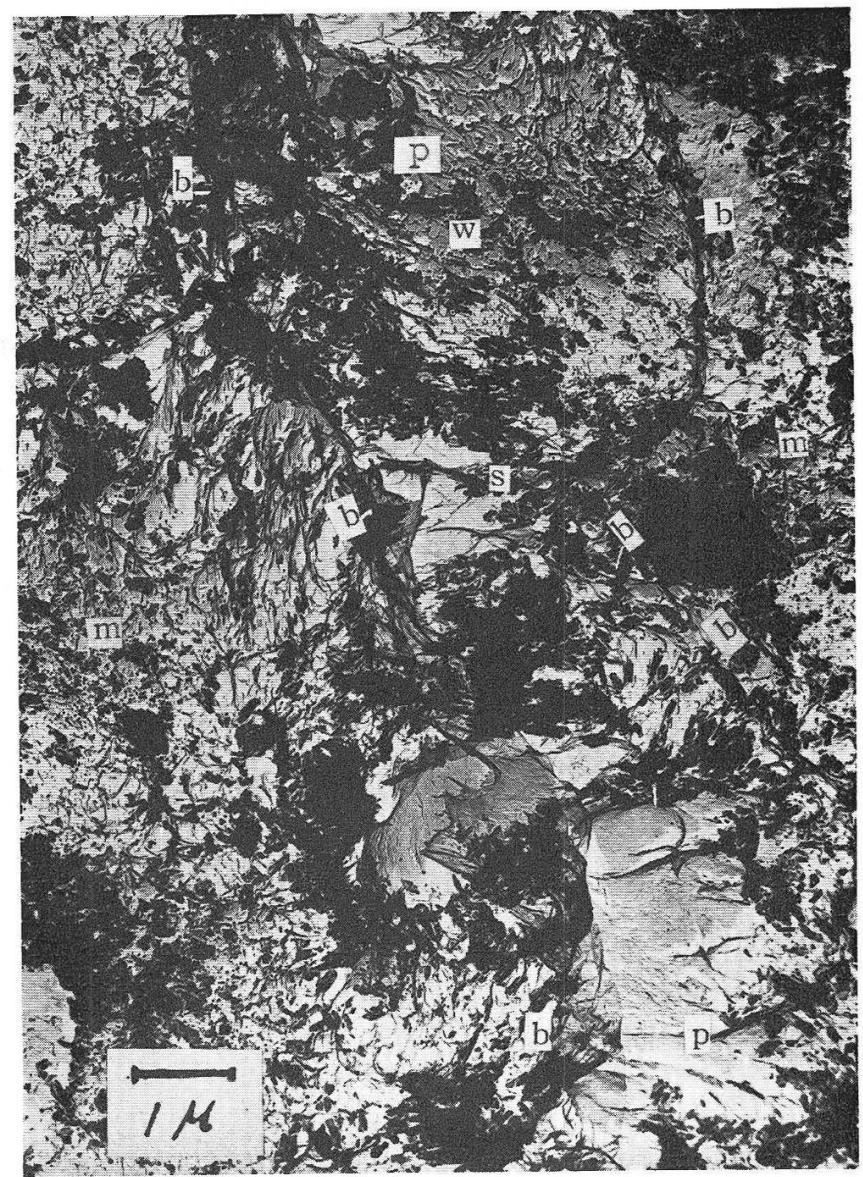

Fig. 9. The electron micrograph of another part of the lamella shown on Fig. 8. $w$ enamel lamella, $b$ border between the enamel and the lamella, $p$ possible rod in the lamella, $m$ enamel. 


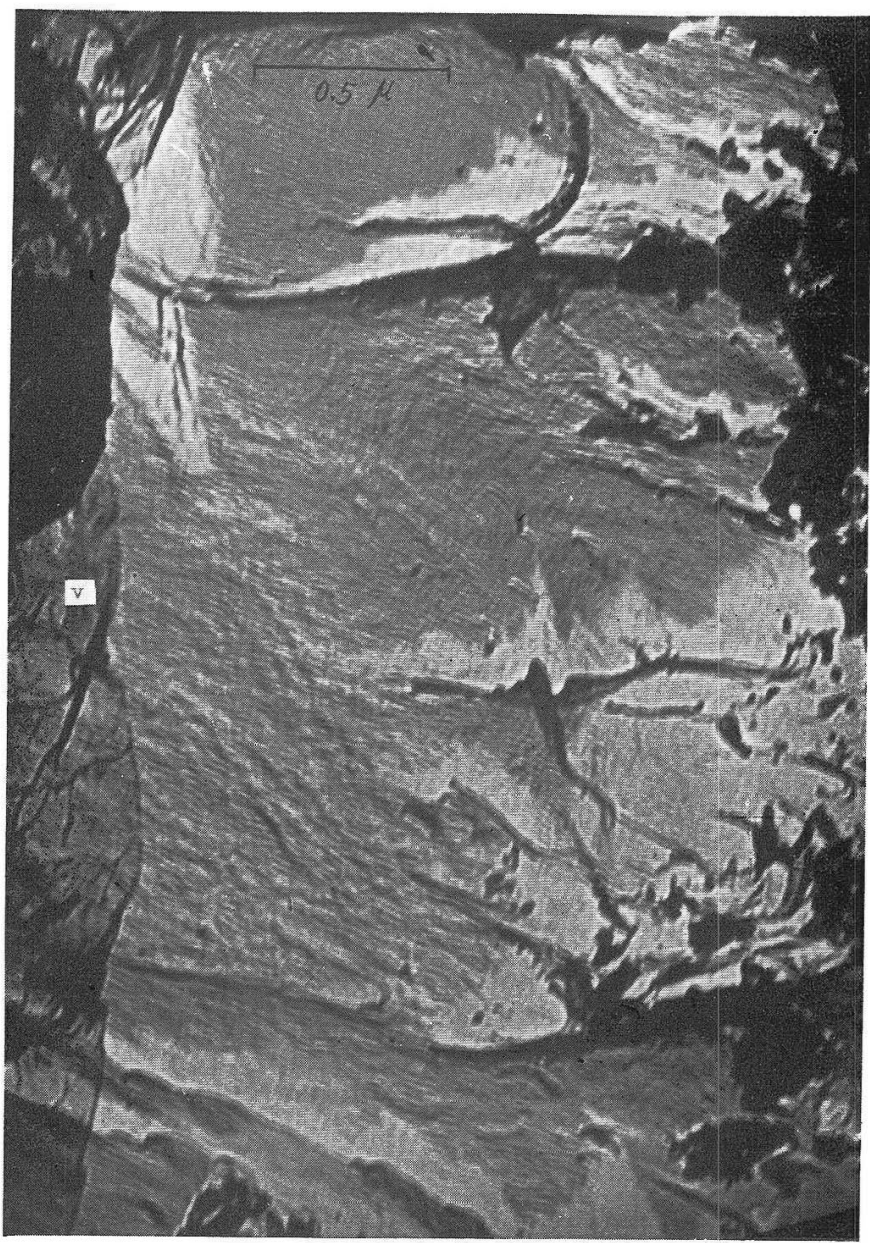

Fig. 10. The partial enlargement of the lower part of Fig. 9. There are clearly observed numerous fibrils scattered in a rather parallel manner in the sectioned rod in the lamella. These fibrils strongly resemble collagenous fibrils. $v$ rod sheath in the lamella, exposed by decalcificution.

\section{B. Bovine enamel lamellae.}

Fig. 11 shows a part of the lamella on the lingual side of a bovine $\overline{M_{1}}$. The outline of an enamel rod is seen in the tissue of lamella. 'The abundance of organic tissue in the rest of the lamella makes it difficult to ascertain the outline of enamel rods. Despite these findings, the author believes that there may be no substantial difference histologically between the enamel and the lamella in the distribution of organic matter.

Fig. 12 shows a part of the lamella seen on the lingual side of bovine $\overline{M_{1}}$. 


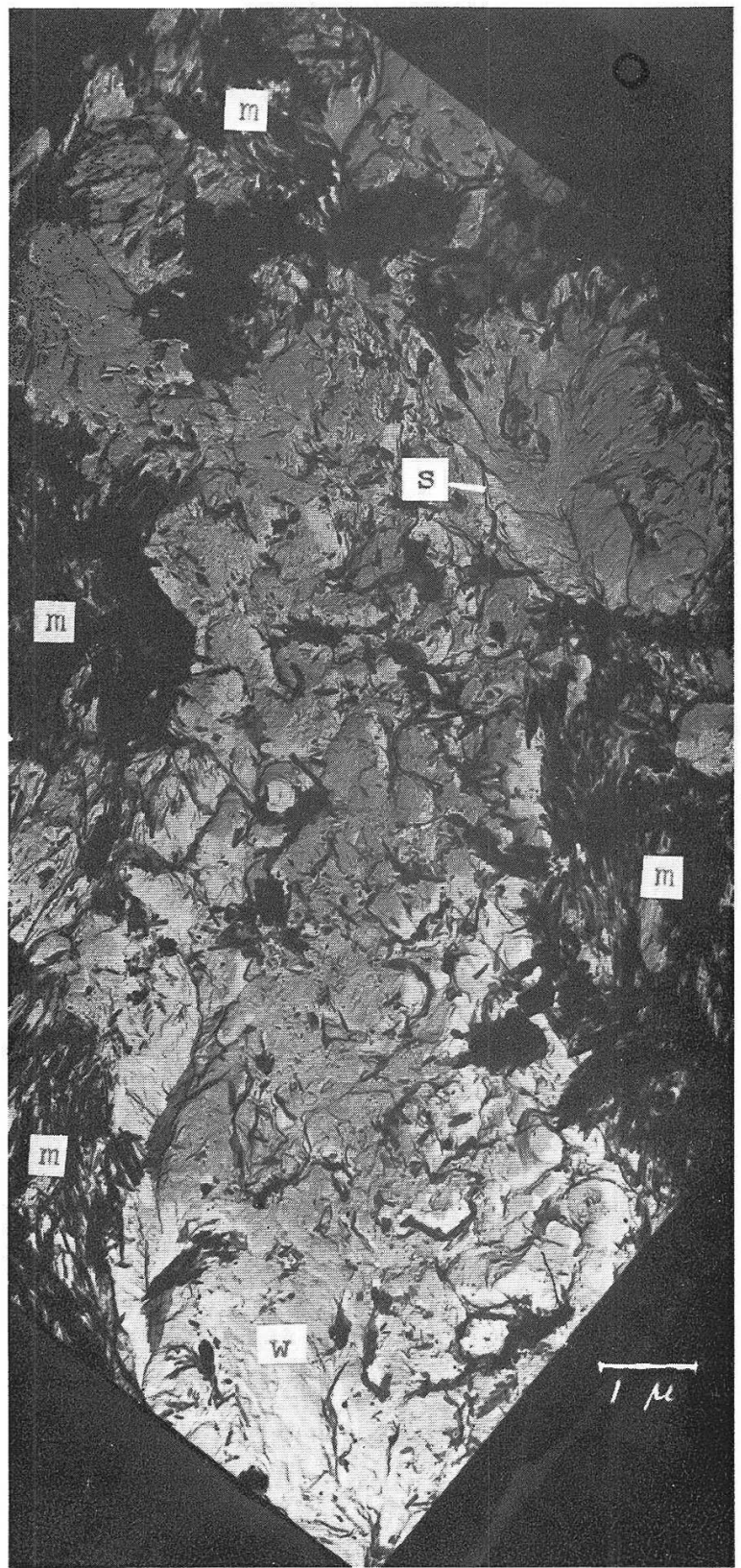

Fig. 11. 1he elechron milrugrapn of a part of the enamel lamella on the lingual side of a bovine $\overline{\mathrm{M} 1}$. $w$ lamella, $m$ enamel. $s$ rod sheath in the lamella. A rod is surrounded by $s$. The outer layer of one fourth of the enamel width was ground off, etched with 2 percent HCI for 4 sec., filmy replica shadowed with chrome-carbon. 


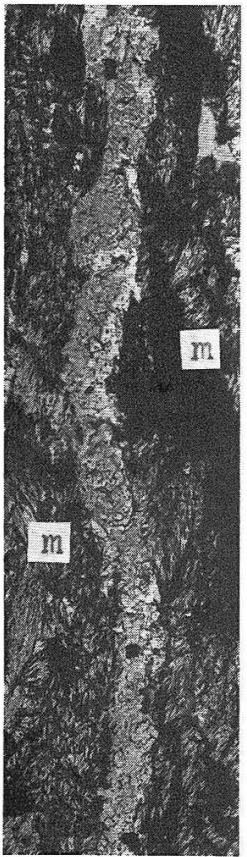

Fig. 12. The electron micrograph of a part of lamella seen on the lingual side of a bovine $\overline{\mathbf{M}_{1}}$. The clear lamella that runs up and down in the figure. $m$ enamel. The outer layer of one fourth of the enamel width was ground off, etched with ? percent $\mathrm{HCl}$ for 4 sec., filmy replica shadowed with chromecarbon. $\times 1,500$

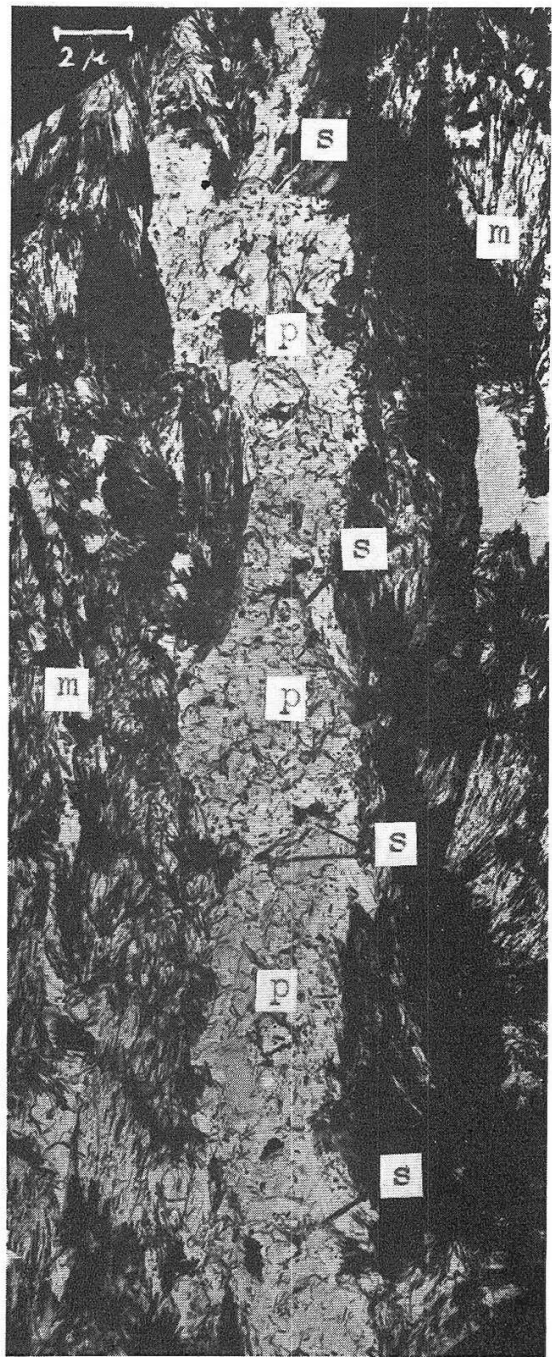

Fig. 13. The partially cnlarged micrograph of the upper half of Fig. 12. Three likely rods in the lamella are clearly observed. Abundant organic matter is diffusely distributed in the sectioned rods in the lamella. These three rods in the lamella are arrayed singly. $m$ enamel, $p$ rod in the lamella, $s$ rod sheath in the lamella. Parts of $s$ involve inter rod substance. 


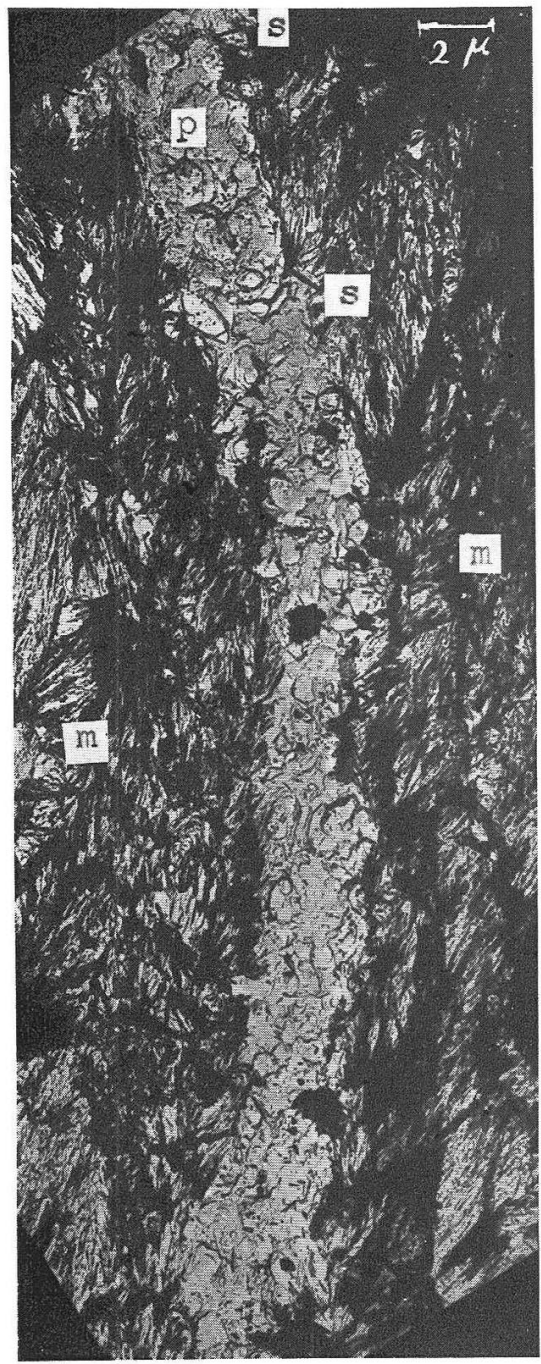

Fig. 14. The magnification of the lower part of Fig. 12. $p$ rod in the lamella, $s$ rod sheath in the lamella.

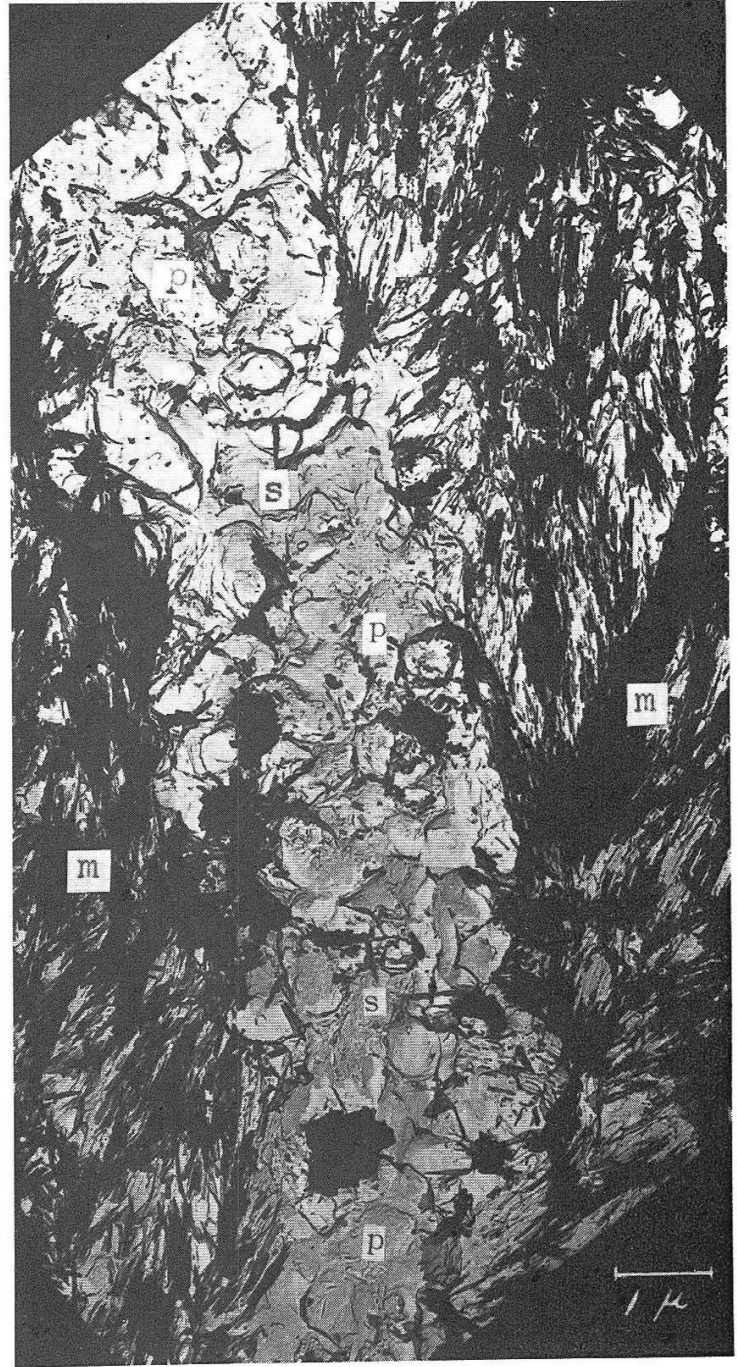

Fig. 15. The partial magnification of Fig. 14. There are observed three likely rods in the lamella, one of them being situated in the upper part, another in the central, and another in the lower respectively. These three rods in the lamella are arranged in a single line. $m$ enamel, $p$ rod in the lamella, $s$ rod sheath in the lamella. 


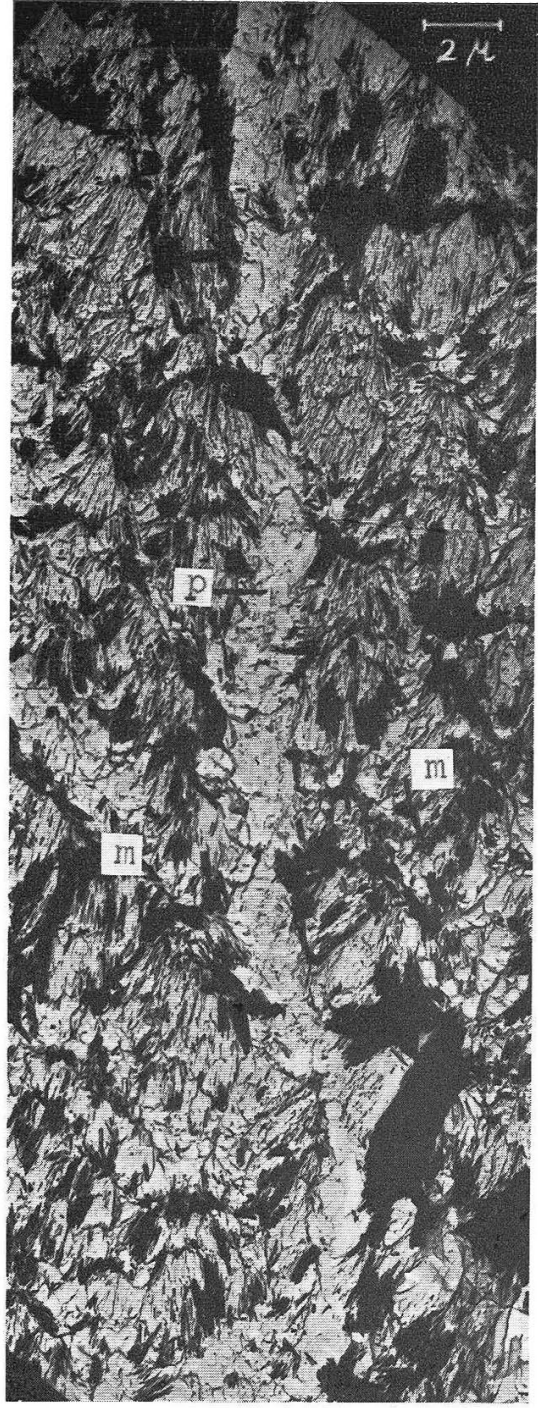

Fig. 16. The electron micrograph of a part of the enamel lamella found on the buccal side of a bovine $\overline{12}$. The lamella lying up and down in the figure looks clear. $m$ cnamel, $p$ rod in the lamella. The outer layer of one fourth of the enamel width was ground off, etched with 2 percent $\mathrm{HCl}$ for 4 sec., filmy replica shadowed with chrome-carbon.

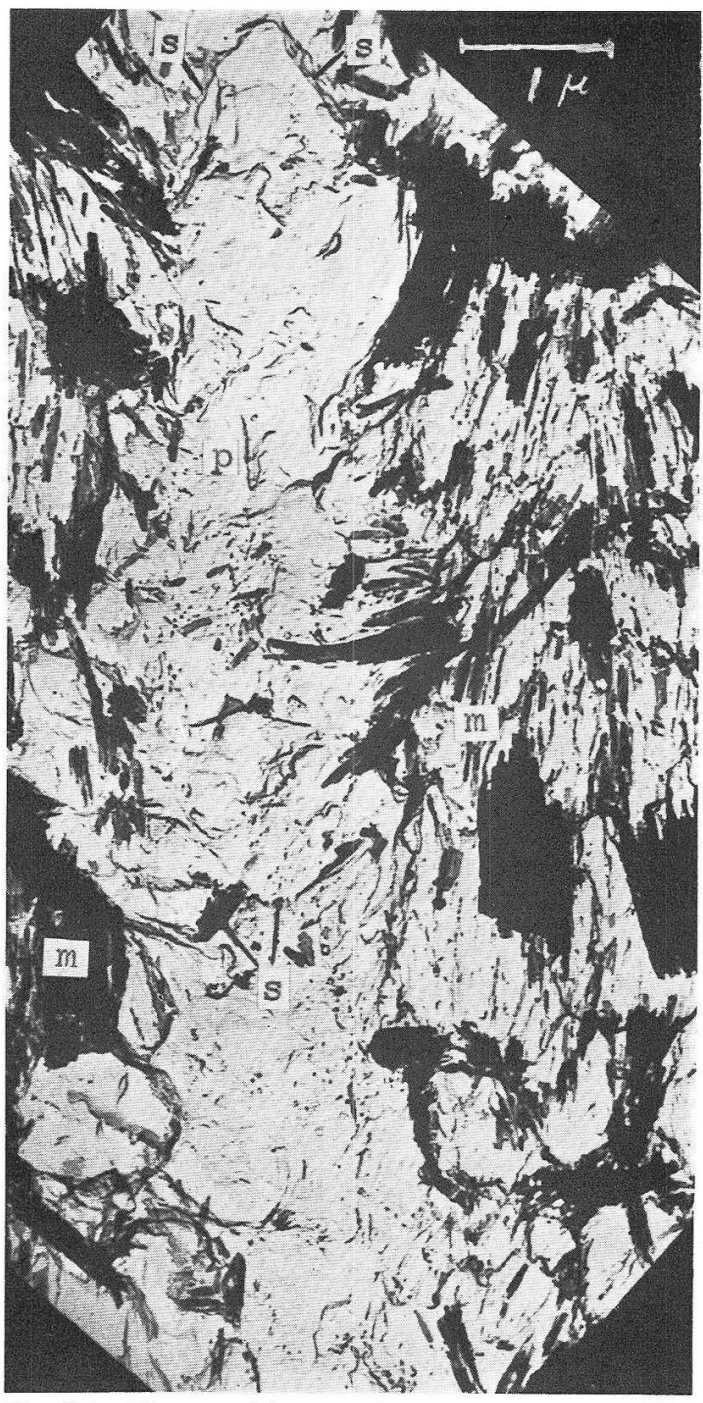

Fig. 17. The partial magnification of Fig. 16. The whole aspect of a possible rod in the lamella is minutely observed. $m$ enamel, $p$ rod in the lamella, $s$ rod sheath in the lamella. 


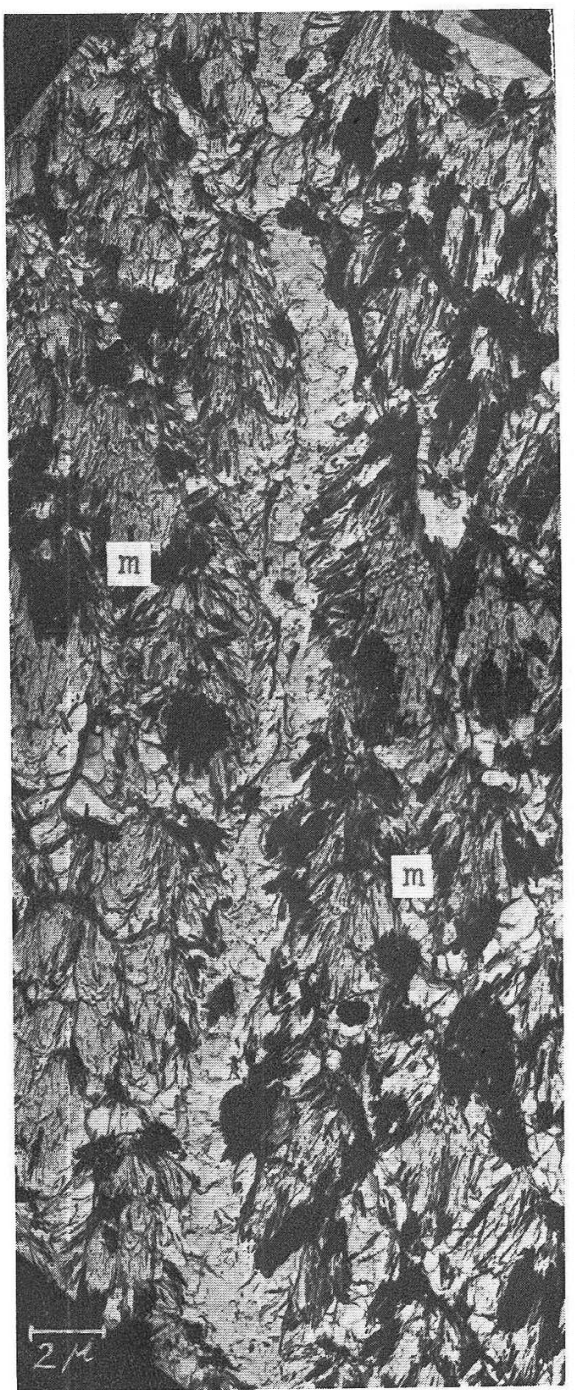

Fig. 18. The electron micrograph of a part of the enamel lamella found on the buccal side of a bovine $\overline{\mathrm{M}_{2}}$. The clear lamella runs up and down in the figure. $m$ enamel. The outer layer of one fourth of the enamel width was ground off, etched with 2 percent $\mathrm{HCl}$ for 4 sec., filmy replica shadowed with chrome-carbon.

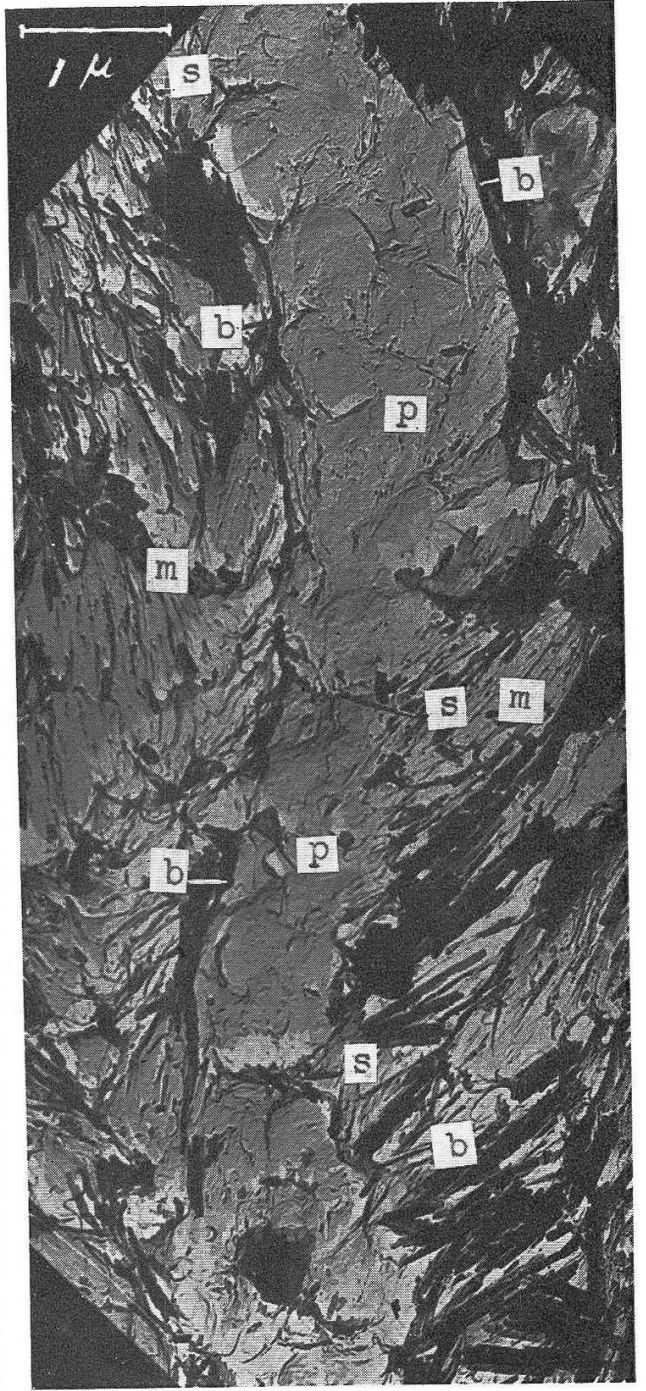

Fig. 19. The partially magnified micrograph of Fig. 18. Two probable rods in the lamella are clearly observed. Accordingly, rod sheaths are seen around these rods. $p$ rod in the lamella, $s$ rod sheath in the lamella, $b$ boundary between the enamel and the lamella, $m$ enamel. 
It is the clear lamella that runs up and down in the figure. Fig. 13 is a partially enlarged microphotograph of the upper half of Fig. 12. Three likely enamel rods are clearly seen in the lamella. Abundant organic matter is diffusely distributed in the rods. These three probable rods in the lamella are arranged in a line. Fig. 14 is the magnification of the lower part of Fig. 12. In the upper part of the figure, probable rods are seen in the lamella. In the other part of the lamella, we recognize abundant organic matter as seen in rods in lamella. However, it is somewhat difficult to judge the outlines of rods in lamella.

Fig. 15 is a partial magnification of Fig. 14. Three likely rods in the lamella, one of them situated in the upper part, another in the central, and another in the lower respectively are seen. However, their borders are not clear enough. Distinction of the rods in the lamella may be obscured by the abundant organic matter. This matter makes it difficult to distinguish the rod sheaths or interrod substances from the organic matters distributed in rods. These three supposed rods in the lamella are arranged in a line.

Fig. 16. shows a part of the lamella on the buccal side of an adult bovine $\overline{\mathrm{M}_{2}}$. It is the clear lamella which lies up and down in the figure. Fig. 17 is a partial magnification of Fig. 16. We see a suspected rod in the lamella because of its size, form and structure. In this figure a rod sheath is seen enclosing the rod in the lamella. Irregular square and oval appearances in the rod have been formed as the result of dispersed organic matter.

Fig. 18 is a part of the lamella found on the buccal side of an adult bovine $\overline{\mathrm{M}_{2}}$. It is the clear lamella that runs up and down in the figure. Fig. 19 is the further magnified photo. of a part of Fig. 18. There are two enamel rod appearances in the lamella that are clearly perceived. Accordingly we see rod sheaths around the rods of lamella. The boundaries between the enamel and the lamella appear clearly.

\section{Discussion.}

As a result of these investigations by means of the electron microscope, we arrive at the general conclusion that the lamella tissue is calcified to a lower degree. In other words, it is enamel with much organic matter. Except for the wider lamellae, they seem to be composed of organic enamel rods arrayed singly. Furthermore, casual observation reveals that the tissue structures of enamel lamella are often more complex than those of enamel. The reason why the lamella tissue is so observed may be that difficulty in distinguishing the rod sheath and interrod substance, which form the rod surface, from the abundant organic matter in the rod contributes to the lamella tissues' complex appearance.

Parts of some lamellae are less than one micron in size. These parts seem to consist only of interrod substances which contain more abundant organic matter than is contained in those of normal enamel. These narrow parts of lamellae contained no rods or rod sheaths that we observed. we reported in 1958 the measurements of lamellae found in cattle, humans, monkeys and cats. This report indicates that cattle lamellae vay in maximum widths from 11.4 to 286.7 microns, while 
humans vary in maximum widths from 0.6 to 30.8 microns.

A half century ago (1909) BÖDECKER discovered enamel lamellae. In the interim between that time and the present the lamella's tissue has not been histologically defined with any degree of exactness. Consequently, the lamella's histological description is highly disputed today. Fomer reported electron microscope observations could not be found by the author. So perhaps this is the first investigation of the lamella's histological nature with the use of the electron microscope. The observations seem to give a signifieant insight into the composition of the lamellae.

Those findings support the opinions of BÖDECKER, MEYER, BAUMGARTNER, and WALKHOFF that the lamella is imperfectly calcified enamel. The author's observations contradict the opinions of GOTTLIEB and ORBAN. In reference to the opinions of GRÄFF, AKAMATSU, and SCHULZ, in 1958 the author pointed out that ground enamel sections with no enamel lamella and no enamel fracture can be prepared (described by the author in 1958). Sometimes such specimens can be made from human teeth. Such ground cross sections can be often obtained from capric molars and second bicuspids except the occlusal surfaces and occlusal areas of the lateral surfaces of the tooth crowns, where enamel lamellae are usually found. Some investigations previously considered the lamellae to be fracture lines caused from specimen preparation, however the author is quite certain that they have prepared specimens in which no fracture lines existed that could be mistaken for lamellae. Few, if any, investigations today believe that fracture lines and lamellae are related.

\section{Summary.}

Human and bovine enamel lamellae were examined with the electron microscope. The microscope revealed the following:

1. The lamellae consist of enamel rods and interrod substance which contain more organic matter than those of the normal enamel. Most lamellae, except unusually wide one, contain rods arranged in a single line. Parts of lamellae less than one micron wide are composed only of interrod substance. (On ail surfaces of the coronal portion of the tooth except the occlusal, casual or detailed inspection reveals that lamellae usually run parallel to the long axis of the tooth. On the occlusal surface they follow on unpredictable direction.)

2. Lamella tissue is often more complex than enamel tissue, in fact, casual observation occasionally reveals no complexity.

3. The observed complexity is possibly caused by the difficulty of distinction between rod sheaths and interrod substance and the manner of organic matter in the lamella.

4. The border between the enamel and lamella seems to be a direct connection. No tissue that could be considered a border tissue seems to exist.

5. Portions of the border between the lamella and enamel sometimes show no rod sheath in areas when rods in the lamella or enamel are against the border.

6. Along the border of human lamellae, there is often seen a thin membrane 
which is interconnected rod sheaths in the lamella, This membrane is almost never seen in bovine lamellae. This membrane was not destroyed by the decalcification process. The decalcification process broke up the bovine rod sheaths into pieces probably because the bovine lamella contains less organic matter.

\section{内容自抄。}

ヒトとウシの正常で新鮮な永久窲のエナメル葉を電子顕微鏡で観察した。その 結果下記の如き所見を得た。

1.エナメル葉は正常なエナメル質に較ベて有機成分に非常によく富んだエナ メル小柱と小柱間質で構成されている。乙のエナメル葉は葉特有の形態をなし, エナメル質中を走行している。幅径の大きなエナメル葉を除くと，有機成分によ く富んだエナメル小柱が 1 列に排列して葉を構成している。時として葉の一部で 1 ミクロン以下の幅径の部分が見られる。乙の部分は正常な小柱間質よりも有機 成分に富んでいる小柱間質だけで構成されている。

2. エナメル葉は有機成分に非常によく富んでいる結果, 葉の組織を構成する 小柱鞘，小柱間質と小柱に分布している豊富な有機質との区別は可成紛らはし い.

3. エナメル葉とエナメル質との境界は両者が互に直接接合して形成している.

4. エナメル葉は部分的に時として小柱鞘や小柱間質を伴うことなく正常なエ ナメル質と接合している.

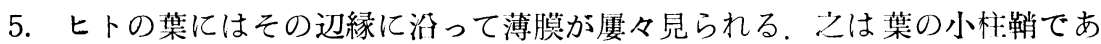
って，互に隣在の小柱鞘と連結したものである。ウシの葉には認めない，ヒトの 葉はウシの葉よりあ遙かに有機成分に畠んでいるため，ヒトの小柱鞘は酸に対し 抵抗が強く，その結果残存して観察されたものである。一方ウシの小柱鞘は酸に 抵抗が弱く，破壤され消失したのである。

\section{References.}

Akamatsu, K.: Nochmals zur traumatischen Fntstehung der sog. Lamellen und Büschel des Zahnschmelzes. Vjschr. Zhk. 44 (1928). - Awazawa, Y. : Staining method for differentiating enamel lamellae from artificial splittings. (Jap. with Engl. abstr.) Act. anat. nippon. 27 (1952). - On the histological nature of the enamel lamellae, and consideration of their appearance. (Jap. with Engl. abstr.) Arch. hist. jap. 5 (1953). - Histometric study on the genuine enamel lamellae of several kinds of mammals. Arch. hist. jap. 15 (1958). - Baumgartner, E.: Über das Wesen der Zahnkaries mit besonderer Berüksichtigung der Histologie des gesunden und kariösen Zahnschmelzes. D. Mschr. Zhk. 29 (1911). - Bödecker,C. F.: Vorläufige Mitteilung über organishe Gebilde im menschlichen Zahnschmelz. Anat. Anz. 34 (1909), - Ebner, V. v.: Histologie der Zähne mit Einschluß der Histogenese. Scheffs Handbuch der Zahnheilkunde. Bd. 1. Berlin u. Wien, 1922. - Gottlieb, B. : Ätiologie und Prophylaxe der Zahnkaries. Z. Stomat. 19 (1921). - Gräff, S•: 
Zur Frage der Entstehung der Lamellen und Büschel des Zahnschmelzes. Verh. dtsch. pathol. Ges. 18 (1921). - Meyer, W.: Schmelzlamellen und Schmelzbüschel. D. Mschr. Zhk. 41 (1926). - Orban, B.: Schmelz- und Zahnoberhäutchen. Schmelzlamellen und Büschel. Z. Stomat. 24 (1926). - Schulz, H. : Schmelzsprünge oder Lamellen? Z. mikr.-anat. Forsch. 33 (1933). 